Without interrupting school work, the teacher could keep a register of the height and weight of every child, noting any defeets in sight, hearing, breathing, mental and physical condition, so that when the medical inspector calls, he need only specially inspect the defective children, and these would be very few, as the children in our rural schools are generally the picture of health.

That such modifications of the Act will be allowed, once teachers are trained, is very likely, and under such circumstances, I consider that the first three directions of the Memorandum could be best undertaken, in rural districts, by the medical officer of health becoming the inedical inspector of school children.

With regard to the fourth direction, for the supervision of the home life of neglected children, I would certainly make use of the district and maternity nurse, who is now becoming established in most rural parishes. These nurses have generally two or three schools in their district, and given some extra remuneration, could easily become both school nurses and health visitors, co-operating with the teachers and the medical officer of health in the supervision of the hygienic condition of the home life of neglected children.

On these lines I consider that the medical inspection of school children, in rural districts, could be more efficiently carried out by the medical officer of health than by a wholetime inspector; besides it could be done more economically, which must be a consideration to the education authorities, as the expense, owing to the state of the Imperial Exchequer, is certainly to be borne by the local taxpayer.

\section{INSANITARY STRUCTURAL DEFECTS ON NEW VESSELS.*}

Br J. HOWARD-JONES, M.D., D.Sc., C.M., Medical Officer of Health, Newport.

IN previous reports I have drawn serious attention to the gross mistakes in the accommodation provided in some new vessels, in spite of the supervision of the Board of Trade.

July 19th, 1907. A steamer arrived at Newport on her maiden trip straight from the builder's hands on the Clyde.

The forecastles provided accommodation for three men on either side. The Board of Trade require a certain amount of free floor space per

\footnotetext{
* From the Annual Report to the Newport Port Sanitary Authority, 1907.
}

head. This was provided, but a good part of it consisted of acute angular spaces, too narrow for any practical use, which contravened the requirements in spirit. The forecastles formed a well about four feet below the level of the deck from which it was approached by steps. The ship's side formed the larger portion of the walls of each forecastle-this consisted of bare iron walls which, in certain conditions of temperature, etc., stream with moisture owing to condensation.

The floor drained into a well with a wooden cover, and provided with a hand pump; this well also received the drainage from the chain lockers, which drainage consisted of the filth from the anchor chains picked up from the bottom, etc., of docks! On examination, this well was found to be full of a black stagnant fluid.

The chain receptacles or lockers were in the forecastles and extended from floor to ceiling; each consisted of a wooden structure with open joints. The fermenting and offensive contents of these lockers would therefore ventilate into the forecastles; nevertheless four midship's bunks were placed against these chain lockers.

The men's provisions were placed in lockers at the ends of their bunks, in narrow recesses, in the eyes of the forecastle. Even under the best of conditions the storing of perishable foods in sleeping and living apartments cannot but be regarded as a grave breach of the laws of domestic hygiene; but in this instance the food had in addition to be stored amid foul emanations from dock water and mud and the drainage from the floors of the forecastles.

The structural defects were not, however, confined to the crew's spaces.

The chief engineer's cabin on the port side, and the second engineer's and cook's cabins on the starboard side were amidships adjoining the engine room, and separated from the latter by iron bulkheads. They were entered by doors opening from the engine room, and, therefore, were supplied with hot moist air from the engine room, in which the ends of the boilers were exposed.

Behind, or aft, the quarters of the second engineer and cook was the galley, with its cooking stove, which was placed against the partition separating it from the said cabin. The heat from the stove was so great that the paint in this cabin had already been blistered by it, 
Such examples surely form a serious indictment against the authorities responsible for permitting insanitary conditions of the kind to be perpetrated in new vessels.

Inspector Roberts has drawn attention to the insanitary methods of storing food obtaining on ressels carrying Lascar crews. The custom is to hang the meat, and store rice, dricd fish, flour and other edibles, in the forecastles, which are frequently occupied by thirty or forty or more men, both as living and sleeping apartments; these quarters also contain casks, boxes, etc., in addition to the men's bunks, so that under such conditions it is extremely difficult to keep them clean.

Fresh water tanks or casks are also kept in such forecastles; these are oftentimes in a filthy condition.

\section{TUBERCULOSIS IN GUERNSEY CATTLE.*}

BY H. DRAPER BISHOP, M.D., M.R.C.S., L.R.C.P., Medical Officer of Health, Guernsey.

$\mathrm{T}^{\mathrm{H}}$ HE publication of the second interim report of the Royal Commission upon Tuberculosis in 1907 has only confirmed previous knowledge and brought no new facts to light.

Although there are slight differences between human and bovine tubercle bacilli, these are relatively unimportant, and the broad facts remain that human beings develop tuberculosis from bovine bacilli, and cattle from human bacilli.

We must now consider a question of more than ordinary interest to our community, the relation of tuberculosis to Guernsey cattle.

The Guernsey cow is well known, not only for the abundance and rich quality of its milk, but for its freedom from tuberculosis. It has always been kept pure in breed, no intermixture with any other strain laving been allowed.

No animal which had left the island was ever allowed to return unless conveyed at once to the State's abattoir and there slaughtered, the only exception to this rule being in the case of cattle sent away for exhibition purposes. It is difficult to imagine the reasons which led to this exception being allowed, but the recent Ordinance is a wise reversion to former practice and entirely forbids it.

The chief export trade of Guernsey cattle

* From the Annual Report on the Health of Guernsey, $190 \%$. has been to the United States and Canada, where the breed was highly esteemed, and the veterinary experts of these countries, after testing large numbers of them with a negative result, came to the conclusion that they were immune from tuberculosis, and so allowed them to be shipped without being tested. This was the position until the autumn of 1906, when, like a bolt from the blue, came the news that some animals which had been shipped to the United States hal been found to be tuberculous shortly after being landed there.

The United States Inspector then stated that he had received instructions from his Government to test all animals before shipment, and added that in his opinion the disease had been introduced into the island by means of cattle sent to English shows, afterwards returning to Guernsey.

Inquiries showed that although other animals of the suspected herd had been affected with tuberculosis, no other herd in the island had been affected.

The Royal Court promptly passed a drastic Ordinance dealing with bovine tuberculosis and forbade the importation of cattle which had been sent away for exhibition purposes.

In spite of the wholesale testing of cattle by the United States and Canadian Governments' inspectors since this date, no animal has been found to re-act to the tuberculin test.

A comparison with the results of similar testing amongst cattle in England is most significant. During the hearing of a recent case in the English Law Courts, Professor MacFadyen stated that there was abundant evidence to prove that in England not less than 20 per cent. of the adult cattle were affected with tuberculosis to some extent; and $\mathrm{Mr}$. Wm. Owen Williams, F.R.C.V.S., veterinary surgeon to H.M. the King, stated that he knew that thirty-six out of the forty cows belonging to the late Queen Victoria were tuberculous. No aninal out of the last 1,000 cattle bred and reared in Guernsey, which has been killed in the State's abattoir, has been condemned on account of tuberculosis, and every carcase has been examined by the State's Veterinary Inspector, Major G. D. Whitfield. These statements show how remarkable is the immunity from tuberculosis of Guernsey cattle, and even if they had no other good qualities to recommend them, the breed should be even more highly prized than it is at present. 